\title{
REGULATORY INTERVENTIONS, CENTRAL BANK SUPPORT, AND OFFICIAL OVERSIGHT AND CONTROL OF WHOLESALE INTERNATIONAL FINANCIAL MARKETS
}

\author{
Tomáš Křížek ${ }^{1}$ \\ ${ }^{1}$ Vysoká škola ekonomická v Praze, Fakulta financí a účetnictví, Nám. W. Churchilla 4,130 67Praha 3 \\ Email:tomas.krizek@gmail.com
}

\begin{abstract}
The aim of the article is to answer a question to what extent the recent crises in international financial markets have confirmed the need for formal regulatory intervention and for official central bank support and subsequently, to what extent transactions in wholesale international financial markets should be subject to official oversight and control or if they can be left to internal market devices. The paper begins with an analysis of major financial disruptions in the last 20 to 25 years from which key findings and conclusions are derived. Subsequently, particular forms of market failure are analyzed with regard to the need of oversight and control of international financial transactions. The author concludes that wholesale international financial markets can be mostly governed by internal market devices. Nevertheless, governments and central banks should have suitable tools of oversight and control of financial transactions and regulatory means of intervention at disposal once the stability of international financial system is at risk.
\end{abstract}

Keywords: financial regulation, financial transactions, international financial markets, oversight and control.

JEL classification: G15

Doručeno redakci: 29.3.2011; Recenzováno: 15.12.2012; 17.1.2013; Schváleno k publikování: 13.3.2013

\section{Introduction}

In its first part, this article answers a question to what extent the recent crises in international financial markets have confirmed, or undermined, the need for formal regulatory interventions and for official central bank support and in the second part to what extent transactions in wholesale international financial markets should be subject to official oversight and control or if they can be left to internal market devices. Even though the article focuses on international financial markets in general, several examples will be given from the UK financial regulation. The first part defines the terminology first, briefly sums up recent development in financial markets and discusses recent financial crises witnessed during the last 20 to 25 years; subsequently, key findings and conclusions with regard to the need of official regulatory interventions and central bank support are derived. The second part defines its scope first and then continues with discussion how particular types of market failure support the idea that wholesale international financial markets should be subject to official oversight and control. Key answers and findings are summarized at the end of the paper.

\section{Need for regulatory interventions and central bank support}

\subsection{Definition of terminology used}

At first, it is necessary to define how to understand the 'formal regulatory intervention and the official central bank support'. Both the words 'formal' and 'official' will be treated as denoting that the interventions and support should be based on written regulatory rules and the actions taken should follow prescribed procedures. In such a case, the official central bank support tools should be of the same character as its tools to achieve its primary objectives ${ }^{1}$.

\footnotetext{
${ }^{1}$ Usually price stability, financial markets stability, economic growth including high level of employment, interest rate stability and foreign exchange stability, and stability of payment systems; based on Bank for
} 
Based on meaning of 'intervention' ${ }^{2}$ and discussion above, 'formal regulatory interventions' shall cover one-time actions and tools based on statutory provisions ${ }^{3}$ but banking regulation itself, e.g. the US Dodd-Frank Wall Street Reform and Consumer Protection Act $^{4}$, the UK Banking Act 2009 or Basel III rules will not constitute 'formal regulatory interventions' even though they may introduce relevant provisions for them. Therefore the essay will focus on the need for statutory based government ${ }^{5}$ and central bank tools to be applied in case of market disruptions or financial crisis. Such 'crisis management ${ }^{\prime 6}$ tools as opposed to crisis prevention tools $^{7}$ may consist mainly of lender of last resort and liquidity management facilities ${ }^{8}$, troubled assets purchase programs ${ }^{9}$ and special resolution regimes ${ }^{10}$.

\subsection{Recent development in financial markets}

Economic cycles usually range from long-term to shorter term ones and are very difficult to control. They relate not only to the 'real sector' but also the financial sector - lenders are optimistic in upturns implying higher and sometimes even excessive levels of credit and pessimistic in downturns after having experienced increasing defaults. Even if capital requirements ${ }^{11}$ and regulation in general succeed in smoothening the cycles ${ }^{12}$ no regulation can fully anticipate market development and other exogenous effects and thus prevent all crises. Recent sophistication of financial instruments, technical improvements and financial innovations provide for development not anticipated only a few decades ago - progress of securitization and structured finance, high-speed computer assisted trading, enormous growth of OTC derivatives markets and their liquidity as well as expansion of short selling, margin trading and automated stop-loss orders, fast increase of assets under management of often highly leveraged and risky hedge funds, etc. Financial regulation is also unable to keep pace with market deregulation, emerging markets and generally lower barriers to capital movements and lower transaction costs. Such a developing environment led to financial crises in South East Asia, speculative attack on British currency, banking crises in several CEE countries during their transition to market-based economies and it can also imply unanticipated impacts of particular regulatory changes - e.g. amendment of the US thrift regulation and subsequent crisis during second half of 1980s' and beginning of 1990s'.

Even despite extensive financial regulation, financial markets will always find ways how to combine various market conditions into profitable but very often risky opportunities. Such behaviour would not itself be able to cause financial crises if all associated risks were

International Settlements, Roles and Objectives of Central Banks, in Issues in the Governance of Central Banks. BIS, 2009, pp18-21.

2 'To intervene'- to intentionally become involved in a difficult situation in order to improve it or prevent it from getting worse. Cambridge Dictionaries Online, http://dictionary.cambridge.org/dictionary/british/intervene_1

${ }^{3}$ E.g. special resolution regimes (SSR) in the UK Banking Act 2009.

${ }^{4}$ The Dodd-Frank Wall Street Reform and Consumer Protection Act (Pub.L. 111-203, H.R. 4173).

${ }^{5}$ Including regulatory and supervisory agencies and, if not strictly distinguished, also the central bank; in this sense 'government' is equivalent to the UK 'tripartite'.

${ }^{6}$ Walker, G.A., Credit crisis, Bretton Woods II and a new global response: pt 2, Butterworths Journal of International Banking and Financial Law, February 2009, pp75-81.

${ }^{7}$ See e.g. Council of the European Union, Council conclusions on crisis prevention, management and resolution. EU Council, Brussels, 2010.

${ }^{8}$ Mostly open market operations, discount windows, auction facilities, securities lending, etc. See e.g. Federal Reserve Bank of New York, Forms of Federal Reserves Lending to Financial Institutions. FRBNY, 2008.

${ }^{9}$ E.g. the US Troubled Assets Relief Program (TARP).

${ }^{10}$ E.g. bank transfer options under the UK Banking Act 2009 - private sector purchaser, bridge bank and temporary public ownership (bail-outs).

${ }^{11}$ In form of counter-cyclical buffer and other capital requirements of Basel III rules.

${ }^{12}$ Which is either very unlikely or it would mean additional costs in terms of lower lending and thus lower profits in times of prosperity and providing higher value of risky loans in time of increased defaults. 
foreseen, assessed and subsequently priced properly. Unfortunately, the risk management is often not adequate. Because the financial crises are considered inevitable for all of the above mentioned reasons, optimum regulatory measures as well as tools for regulatory authorities to reduce consequences of such crises and to accelerate recovery of financial markets must be continually developed. For further discussion it is necessary to analyze which factors may contribute to transformation of individual collapses to market contagion and systemic crises.

\subsection{Overview of recent financial crises}

There have been several major financial market disruptions during the last 20-25 years. Two major stock price declines were recorded in this period - the 1987 Black Monday and burst of internet bubble in 2000/2001. But why the largest one-day stock market drop in history ${ }^{13}$ and the fall in technological companies share prices by around $70 \%{ }^{14}$ did not cause any sever problems on financial markets that would extend to the 'real economy'? First, these market disruptions would have to influence either aggregate demand or corporate costs in form of higher prices of inputs or credit. Aggregate demand was not a problem because majority of consumers were not significantly influenced. Regarding higher costs, share prices do not directly influence costs of input materials or services and the decline was not systematically important for financial institutions to significantly tighten conditions for granting credit or increase the risk premium - not many companies defaulted in 1987 and banks were not heavily involved in proprietary stock trading at that time; in case of the 'dot-com' bubble burst most of the losses were absorbed not by banks but venture investors and speculators.

The US savings and loans crisis during late 1980s' and early 1990s' was much larger systemic threat as the crisis spread through the whole US thrift industry. Moreover, the crisis was able to influence the US aggregate demand through losses incurred by individual consumers having lost their deposits and through decline in real estate market. Even though the savings and loans crisis most probably contributed to the 1990-1991 US recession, the $\$ 160$ billion $^{15}$ government bail-out of defaulting thrifts contributed to faster economic recovery. If financial institutions in troubles were not thrifts, which do not provide corporate funding, but banking institutions the consequences would be more severe as the real economy would be negatively influenced through higher costs of corporate borrowings.

Question is whether bank-related 'scandals' such as Nicholas Leeson's losses of over $£ 800$ million from futures trading at Barings Bank or Jérôme Kerviel's losses of around $€ 5$ billion from 'unauthorized' derivatives trading at Société Générale can undermine market confidence. Even though the losses incurred by Société Générale were much higher than those created by Leeson, Société Générale thanks to its incomparably higher equity capital could absorb the losses. Barings Bank was not large enough and all its liabilities were assumed by Dutch ING, which acquired Barings for nominal sum of $£ 1$, so its collapse could not mean any threat the markets. This is valid also for another bank failure - Bank of Credit and Commerce International which had to start ceasing its activities in 1991 because of its poor risk management and accumulated losses. Despite its fast growth to the world's $7^{\text {th }}$ largest private bank ${ }^{16}$, the bank provided rather simple services consisting of deposit taking, granting loans and providing for payment services than complex investment services and proprietary

\footnotetext{
${ }^{13}$ It was part of one month sudden decline in stock indices ranging from $20 \%$ to $60 \%$.

${ }^{14}$ See NASDAQ Composite Index.

${ }^{15}$ Estimated by Curry, T. - Shibut, L., The Cost of the Savings and Loan Crisis: Truth and Consequences. FDIC, December 2000.

${ }^{16}$ Kanas, A., Pure contagion effects in international banking: The case of BCCI's failure. Journal of Applied Economics, Vol. 8, No. 1, May 2005, pp101-123.
} 
trading resulting in deep interdependencies with other international banks. As also the case of Barings Bank, the losses were absorbed mostly by bank's shareholders and bank's counterparties recovered most of their claims. Even though there can be a 'pure contagion' effects ${ }^{17}$ and decrease in public confidence in banking system only a marginal impact has been registered in the UK due to the BCCI's failure. ${ }^{18}$

Fall of hedge fund Long-Term Capital Management was a different situation. LTCM applied most of the modern speculative techniques - margin trading, short selling, derivatives trading, risky arbitrage trading and it also highly leveraged its portfolio 25 times to more than $\$ 100$ billion (vs BCCI's \$20 billion). Since LTCM was mainly funded by borrowings from banks and investment firms under financial collateral arrangements with a very small 'haircut ${ }^{\text {'19 }}$, its counterparties faced very high risk in case of unanticipated irrational and correlated market movements. Thanks to high leverage and enormous value of open positions compared to total market size, its portfolio was highly price sensitive and illiquid and if LTCM had started to sell major parts of its assets the market would not have been able to absorb the sale. Mark-tomarket valuation of assets affected by the downward spiral would have then triggered margin calls all over the market and the whole market would have collapsed. Even though LTCM was four times larger than BCCI, threat of its fall to market stability was not in terms of total assets but in its interconnection to other financial institutions and its ability to distort market prices in case of forced sale of its portfolio. Eventually LTCM was bailed-out by major Wall Street firms under oversight of the US Fed and gradually liquidated. The additional costs of equity injection to LTCM were heavily outweighed by the benefits of working markets.

Steep decline in prices of highly overvalued assets in Japan in 1989/1990 resulted in accumulated losses from defaulted loans and lower economic growth which lead to banking crisis. In contrast to the LTCM case, inability of Japanese government to provide for prompt and effective market support caused the crisis to continue over the whole 1990s' and hindered fast market recovery. The 1997-1998 Asian crisis, was an example of market interconnection and failure to distinguish among individual countries of South East Asia with different fundamental conditions (indebtedness and currency imbalances).

The current financial crisis can be seen as a complex mixture of the crisis in Japan, Asia and the LTCM crisis. High asset prices (mostly real estate prices) were followed by their steep decline and loan defaults on the US sub-prime market. Contagion effect after disclosure of problems of Bear Stern's and BNP Paribas' investment funds reduced market confidence. Despite several particular disruptions ${ }^{20}$ government and central bank interventions ${ }^{21}$ supported the market confidence, but once Lehman Brothers collapsed lack of market confidence lead to the already discussed unstoppable downward spiral of liquidity shortage, forced portfolio sell outs, price collapses, loan defaults and economic recession. Technical means were almost the same as in the LTCM crisis - high leverage ratios and margin lending with need for additional collateral after the initial price declines, fear of counterparties' failure in OTC derivatives trades, inability to match the maturity gap of assets and liabilities (borrowing short term, investing long term) and lack of trading and investment transparency, but the problems were

\footnotetext{
${ }^{17}$ Jacklin, C. - Sudipto, B., "Distinguishing Panics and Information-based Bank Runs: Welfare and Policy Implications," Journal of Political Economy, Vol. 96, 1988, pp668-592.

${ }^{18}$ Kanas, p120.

${ }^{19}$ Portion of collateral exceeding the amount of borrower's liability.

${ }^{20}$ Fall of Northern Rock and other financial institutions.

${ }^{21}$ Nationalisation of the US FHLMC and FNMA, the UK Northern Rock and Bradford \& Bingley, increased central bank liquidity support, etc.
} 
aggravated by a new phenomenon - securitized instruments which spread the underlying fundamental problems from the US all around the world and fast development of OTC derivatives markets which rose from $\$ 10$ trillion $^{22}$ in 1993 to $\$ 684$ trillion in H1 $2008^{23}$. Subsequent government interventions and central bank support came too late.

\subsection{Key learnings from the recent financial crises}

Modern financial markets are highly interconnected and in case of major market events, the markets start to correlate. This is further strengthened by financial innovations and fast growth in values of securitized instruments and other OTC derivatives. Moreover, high OTC trading creates another type of risk which does not occur at exchanges - counterparty risk, when default of one large OTC institution can influence many others. Modern investment and speculative strategies make the markets highly sensitive to unanticipated market disruptions which can lead to sudden downward spiral. International financial markets are also developing very fast and the financial regulation is very often unable to keep pace; through financial innovations, markets will always find ways how to achieve desired aim without contravening it. Therefore, banking regulation will never be able to prevent crises to occur unless it becomes very strict; in such a case costs of compliance would be too high.

Once a major market disruption occurs, it is necessary to react very fast and support the market before the individual collapses can spread to market contagion and crisis ${ }^{24}$. The earlier the markets are supported, the faster the overall recovery will be. To ensure this, governments and central banks should have tools to improve market confidence and prevent crises to arise - tools to provide sufficient market liquidity and to provide guarantees or purchase programmes for troubled assets. Once such tools are not sufficient to safe individual systemically important institutions from collapse, special resolution regimes should apply to suppress individual 'failure' from spreading into contagion. Further, conditions for contagion might be removed by imposing temporary prohibitions on certain market activities which should be allowed under normal conditions - e.g. short selling and free transfer of short term capital; mark-to-market valuation exacerbating the contagion could be also suspended. Systemic events able to threaten market stability through all the discussed devices and nonsystemic events must be distinguished. 'Isolated' events, such as BCCI, bank scandals or even Northern Rock, Bear Stern's hedge funds and others, can be painful to shareholders and general public but they do not constitute threat to international financial system and thus do not have to be resolved using public funds; if they are supported it is just a political decision.

Even though all available means must be used to prevent systemic collapses, to mitigate their impact and to support market recovery, three conditions must apply. First, all tools must be at disposal before the crisis occurs, markets must be aware of them, and their use must be predictable..$^{25}$ If the tools are created ad-hoc during the crisis they are usually neither effective enough $^{26}$ nor have they the required preventive effect of ex-ante market confidence support. Second, market solutions should always be preferred to government and central bank

\footnotetext{
${ }^{22}$ Comptroller of the Currency, Fact Sheet. News Release, 31 March 1995, OCC NR 95-35.

${ }^{23}$ Bank for International Settlements, Regular OTC Derivatives Market Statistics. 11 May 2010.

${ }^{24}$ To identify the possible systemic threat, international macroprudential oversight should be applied; see Commission of the European Communities, Proposal for a regulation of the European Parliament and of the Council on Community macro prudential oversight of the financial system and establishing a European Systemic Risk Board. Brussels, September 2009 or Trichet, J.-C., Macro-prudential oversight and the future European Systemic Risk Board. European Banking Congress, Frankfurt am Main, 19 November 2010.

${ }^{25}$ As was not the case in different approaches to bail-out support facility for Bear Sterns and Lehman Brothers.

${ }^{26}$ The case of Japan in $1990 \mathrm{~s}^{6}$.
} 
interventions and support. E.g. in case of providing liquidity to the markets, the market ${ }^{27}$ facilities should be applied; as long as the 'market' can ensure enough liquidity for particular institution in troubles, official support should not be applied. Moreover, the support and intervention must be provided under conditions close to the market conditions - interest rate for lending facilities should reflect institution's low creditworthiness, temporary public ownership should be acquired under non-subsidizing terms, etc. The requirement of nonsubsidizing nature of the support provided reflect the last condition - all the means of intervention and support must be constructed in such a way so that they do not create moral hazard. Market participant should be aware that systemically important institution will never be allowed to fail but under strict implications for those who caused the problems. ${ }^{28}$

\section{Official oversight and control of wholesale international financial markets 2.1 Scope of the discussion}

International financial markets can be generally divided into eight main categories - money markets, securities and capital markets, financial derivatives markets, alternative investment markets, currency markets, insurance and reinsurance markets and commodity markets ${ }^{29}$. Financial markets are usually divided according to places of trade into formal stock exchanges for equities, formal exchanges for futures and options, off-exchange - OTC markets, and interbank deposit markets, foreign exchange markets and other money markets. ${ }^{30}$ This essay will rely on functional division - international securities market, international term and syndicated loan market, international bonds and notes market, financial derivatives market, international project finance market and securitized instruments market.

To further specify the scope of the discussion, the terms 'transactions' and 'wholesale' should be defined. 'Wholesale' market as opposed to 'retail' market shall be understood as a market among institutions. Finally, 'transactions' shall mean 'a piece of business that is done between [parties], especially an act of buying or selling' ${ }^{31}$ In the discussion, 'official oversight and control' will consist mainly of financial regulation and interventions; 'internal market devices' shall cover mostly two groups - self-regulation through industry associations and codes of conduct ${ }^{32}$ and basic contractual principles - 'caveat emptor'"33 and "vigilantibus iura scripta sunt ${ }^{34}$ meaning that the parties to international financial transactions should mostly rely on their analyses and risk assessment.

In every industry a suitable level playing field must be created; in financial markets this level playing field should also ensure sound condition of financial markets which may become very unstable due to all the influences discussed further. Consequently, financial instability might significantly influence the 'real economy' by decreasing availability of funds through reduced corporate lending, dysfunction of money and capital markets, and also by possible collapse of

\footnotetext{
${ }^{27}$ As defined by Cecchetti, G.S. - Disyatat, P., Central bank tools and liquidity shortages. FRBNY Economic Policy Review, August 2010, pp29-42.

${ }^{28}$ Conclusion slightly contravenes traditional doctrine of lender of last resort of Thornton and Bagehot.

${ }^{29}$ Revenda, Z. et al, Monetary Economics and Banking. $4^{\text {th }}$ edition, Prague: Management Press, 2005, ISBN 807261-132-1.

${ }^{30}$ Wood, P., Law and Practice of International Finance. University Edition, London: Sweet \& Maxwell, 2008, ISBN 978-1-84703-255-3, p335.

${ }^{31}$ Oxford Advanced Learner's Dictionary, 'Transaction'. Oxford University Press, 2010. Available at http://www.oxfordadvancedlearnersdictionary.com/dictionary/transaction.

${ }^{32}$ Sheng, A., Lecture to the Macquiarie University MA (Finance) Programme in Hong Kong. Bank for International Settlements Review, BIS, 55/1997, p1.

33 'Let the buyer beware' doctrine in broader sense applicable also to other transactions other than sale contracts

${ }^{34}$ Classical Roman doctrine 'laws are written for vigilant parties' similar to one of the maxims of equity -

'Equity aids the vigilant, not those who slumber on their rights'.
} 
particular financial institutions with impact on deposits and payments. For the above mentioned reasons, the financial markets should be regulated; regulation may cover products, functions or institutions or combination of all the three and may be in the form of law, administrative rules, taxation or moral suasion. Once two or more institutions get a permission to conduct their desired function/activity, comply with all continuous requirements ${ }^{35}$ imposed on them and a product ${ }^{36}$ is created $^{37}$ in accord with all prescribed rules, a question arises whether there should be any further possibility of official oversight and control over the actions of such parties with regard to the product or whether such action, or let's call it 'transaction', shall be left self-regulated either by the market or the parties themselves. Usually four reasons for market failure and regulation are discussed ${ }^{38}-$ information asymmetry, market abuse, systemic threat and abuse of dominant market power. Further discussion will follow these four reasons for regulation or more particularly for introduction of market oversight and control.

\subsection{Information asymmetry}

Information asymmetry, a situation when one party to a contract has easier access to information than its counterparty, is mostly a problem in retail financial markets. Individual consumers of financial services and products do not often have enough information about financial products and services and it is difficult for them to obtain information and process it. This is not supposed to be the case of participants on the wholesale financial markets since these participants are either financial institutions with enough human resources to obtain and process all relevant data or larger entities which participate in wholesale markets as they want to achieve economies of scale from their size (further "corporations"). Once these corporations are large enough to participate on the international financial markets, they should also have enough resources available to pursue and achieve their own interests ${ }^{39}$. Sometimes it is difficult to draw a line among persons that deserve protection and the others; usually, the distinction is between individuals and corporation but sometimes also smaller corporations are included in the protected group in case of more sophisticated markets ${ }^{40}$. Another difficulty also arises once the large non-financial institutions enter too sophisticated markets with securities brokers hardly pushing their complex products. ${ }^{41}$ Even though it can be argued that the corporations should be protected almost in the same ways as retail consumers because of the high sophistication and pressure from the securities dealers, the corporations should have internal regulations and limits for individual employees on what speculative/investment positions every employee is allowed to enter into. Moreover, very often the four-eye principle applies or should apply so the internal regulations and limits should be enough to protect the whole corporation from failure of individual employees. Losses from financial transaction can be caused also by collective decision of either top management or company shareholders; in

\footnotetext{
${ }^{35}$ Capital requirements (bank), reporting and disclosure rules, etc.

${ }^{36}$ Either contracts - e.g. loans or investment services, or investment instruments/securities - e.g. shares or bonds. Nevertheless, the distinction between contract and property is blurred - see Pretto-Sakmann, A., Boundaries of personal property law: shares and sub-shares. $1^{\text {st }}$ ed., Oxford: Hart Publishing, 2005, ISBN 978-1841134598 or recent discussion on nature of intermediated securities more generally.

${ }^{37}$ In case of primary markets, the 'product' will have yet to be created among the parties.

${ }^{38}$ The new Palgrave dictionary of economics. Volume 5, $2^{\text {nd }}$ edition, Houndmills: Palgrave Macmillan, 2008, ISBN 978-0-230-22641-8, pp300-303.

${ }^{39}$ View also supported by FSA Conduct of Business Sourcebook, rule COBS 2.1.1 - The client's best interests rule excludes large corporations (as defined by MiFID - see further) from applicability of the protectionist rules. ${ }^{40}$ Based on directive 2004/39/EC of the European Parliament and the Council of 21 April 2004 on markets in financial instruments ('MiFID'), Annex II, I(2), a large non-financial undertaking is classified as a 'professional' client if it meets at least two out of three criteria - size of balance sheet (more than EUR 20 mil.), net turnover (EUR 40 mil.) and own funds (EUR 2 mil.).

${ }^{41}$ See further discussion about the Springwell case.
} 
such a case it is a business decision of the whole company and it should be made fully responsible and accountable for its consequences. The transaction is also regulated by general provisions of contract law based on misrepresentations ${ }^{42}$, unfair contract terms and other rules which protect the parties so there is no need for additional oversight of the transaction and the caveat emptor principle should apply despite some historical examples when corporations failed to introduce sufficient internal rules and limits to financial transactions.

Between 1991 and 1994 Gibson Greetings ended with \$13 mil. loss after attempting to lower their interest rate with complex swap instruments with Bankers Trust. Bankers Trust played also a key role in Procter \& Gamble's losses of $\$ 190$ mil. in 1993 again from transactions with derivatives. There are also other examples - Metallgesellchaft (1993), Orange County (1994), Sumitomo Corporation and others. ${ }^{43}$ Large parts of the losses incurred were either recovered by application of misrepresentation provisions or through out-of-court settlement. Moreover, the market is controlled also by internal 'market oversight' which led to 'underpricing' of Bankers Trust's ${ }^{44}$ shares and its takeover by Deutsche Bank in 1998. In most of the cases the market powers and private law provisions were 'able to ensure reasonable protection' both ex-ante and ex-post. Nevertheless, 'ability to provide protection' does not mean that all investors will use all means of protection - e.g. in Springwell Navigation Corp v JP Morgan Chase Bank [2010] EWCA Civ 1221 (affirming previous decisions [2008] EWHC 1793 and [2008] EWHC 1186) the appellant did not use available contractual means of protection and was consequently denied compensation for losses incurred; even though the classification of the transactions and relationship between the investor and the investment banker was not necessarily correct ${ }^{45}$ in the judgements, if the court have found in favour of Springwell, the caveat emptor principle would have been further weakened ${ }^{46}$. In general, additional oversight and control would mean only additional costs of compliance and administrative costs of regulation, and barriers to market development. Moreover, any means of official oversight and control cannot prevent intentional fraud and abuse of power by individual employees as was the case of Nicholas Leeson (Bearings Bank), Jérôme Kerviel (Société Générale) or Toshide Iguchi (Daiwa Bank/Nomura Bank).

\subsection{Market abuse}

Information asymmetry as discussed above is rather a problem between two (or more) parties to an individual transaction/s but market abuse in form of insider dealing ${ }^{47}$, distortion of prices or dissemination of false or misleading information ${ }^{48}$ is a broader problem of the whole market $^{49}$. Since market abuse does not threaten individuals, who might act under the caveat emptor principle, but rather the whole market which cannot apply any prudential 'collective care', the caveat emptor approach will not be sufficient. Market abuse can lead to decrease in market confidence, distortion of the 'invisible hand' of liberalized markets and final

\footnotetext{
${ }^{42}$ Statutory, tort/criminal misrepresentations.

${ }^{43}$ See e.g. Jilek, J., Derivatives, Hedge Funds, Off-Shore Companies. $1^{\text {st }}$ edition, Prague: Grada Publishing, 2006, ISBN 80-247-1826-X.

${ }^{44}$ Bankers Trust was continually misusing weaknesses and trust of its clients.

${ }^{45}$ The relationship was de facto investment advisory.

${ }^{46}$ From civil/continental law perspective, it is unbelievable how far common law (both in the US and the UK) can suppress such a basic principle of contractual relationship.

${ }^{47}$ Mostly problem of company directors having access to price-creating information that is not yet public;

'Chinese walls' separating advisory and trading departments in securities firms should prevent misuse of internal information across individual company.

${ }^{48}$ Directive 2003/6/EC of the European Parliament and of the Council of 28 January 2003 on insider dealing and market manipulation (market abuse).

${ }^{49}$ Shares, bonds, and derivatives markets rather than the international syndicated and term loan markets.
} 
dysfunction of the international financial markets; for that reason the market abuse should be prevented. Very powerful tools are market rules ${ }^{50}$ which institutional markets (exchanges) impose on their members whereas violation of these rules may result in disciplinary proceeding and fine or other penalty. Limitation of these market devices is the membership principle - non-members are not subject to the oversight and penalties. At this point the transactions by non-members should be subject to official market oversight and control ${ }^{51}$ and if the administrative penalties are not incentive enough to prevent market participants from conducting market abusive activities, also criminal penalties should apply. ${ }^{52}$

\subsection{Systemic risk}

Systemic risk is currently the most discussed kind of market failure. The latest development on financial markets leading to systemic risk and its consequences were discussed in the former parts of the article. Most of the systemic risk is controlled through regulation of institutions and functions - if anybody wants to conduct a special financial function - e.g. taking deposits and providing credit, organizing exchange with financial instruments, offering investment and depository services or clearing and settlement of financial transaction, they need a permission to do so and to keep the permission the entity must comply with strict regulatory requirements ensuring not only stability of individual institution but implicitly also sound condition of the whole financial market. A threatening situation may arise when all market participants' actions start to correlate and follow the same systemically dangerous pattern - selling after market confidence collapse, buying without fundamental reasons and creating market 'bubble', systematically under-pricing the risk, reliance on econometric models without sufficient statistical market data or creating deep interconnections with other financial institutions through over-the-counter traded instruments or when separate individual rational decisions altogether result in a seemingly irrational collective action which cannot be prevented by the 'invisible hand of the market' which is also one of the internal market devices. Most of the above mentioned patterns result from derivatives and speculative trading and are not inherent in the bond or loan markets ${ }^{53}$ which do not separately seem to include any remarkable systemic risk and therefore should not be subject to special control in this respect. Official oversight might be reasonable up to the extent to which it would identify possible general risks that might be magnified by securitization and secondary trading as the primary transactions will probably not be able to expand to systemic threat if they are not securitized and/or traded on secondary markets. In this regard e.g. syndicated loan or project finance transactions might have systemic impacts in case of extensive sub-participation because the sub-participating institutions take also the credit risk of the 'transferring' parties.

To identify possible systemic risk, not only the transactions on highly complex markets derivatives markets - should be overseen but also transactions on the underlying markets as suggested above. It is necessary that the oversight is applied across the markets and analyzes market data in broader perspective - recently suggested macroprudential policies seem to fulfil this objective. If any systemically risky patterns are identified, regulatory authorities should have suitable intervention tools that might be applied to mitigate the risk. These tools

\footnotetext{
${ }^{50}$ E.g. the official Rules of the London Stock Exchange, Chicago Mercantile Exchange Rulebook, Chicago Board of Trade Rulebook, etc.

${ }^{51}$ E.g. part VIII 'Penalties for Market Abuse' of Financial Services and Markets Act 2000 ('FSMA'), mainly

ss118-118C and subsequent FSA Handbook rules - Market Conduct ('MAR').

${ }^{52}$ See market manipulation provisions in s397 of FSMA or Part V - Insider Dealing (ss52-64) of Criminal Justice Act 1993.

${ }^{53}$ This is not true for retail mortgage market when the risk was recently highly underpriced; on the other hand the turmoil on the mortgage market was facilitated mostly through securitization and structured finance.
} 
might generally fall into two groups - tools to regulate financial institutions ${ }^{54}$ and tools to intervene into particular transactions discussed in the former parts of the article. Since large number of transactions is executed on financial markets, the tools to regulate institutions seem to be more effective than formal interventions into individual transactions.

\subsection{Abuse of market power}

The wholesale international financial markets are very competitive, with limited barriers to market entry therefore the abuse of market power does not seem to be very significant as e.g. in utilities markets or other markets with natural monopolies or high market entry barriers. ${ }^{55}$ Just to ensure market competitiveness, M\&A of the biggest financial institutions should be subject to official oversight and control. ${ }^{56}$ Moreover, the competitiveness of the wholesale international financial markets is, with regard to the non-price conditions of the transactions, strengthened by standardization of contract terms in form of master agreements developed e.g. by International Swaps and Derivatives Association or Loan Market Association.

\section{Conclusion}

Recent financial crises and development on international financial markets over the last 20 to 25 years suggest that unless the financial markets are regulated to such an extent that would hinder their function, market development and economic growth, there will always be market disruptions and crises. Suitable regulatory adjustments should be adopted to mitigate the adverse market development which occurs from time to time. So that large systemic crises could be avoided, governments and central banks should have adequate means of formal regulatory intervention and market support at disposal. These tools should be known to the markets and their use should be predictable so that the markets could rely on them in times of low market confidence. Nevertheless, the tools should not create additional moral hazard and the support should thus be provided under conditions close to the market conditions

The wholesale international financial markets are mostly able to protect contractual parties by internal market devices and the invisible hand of the market (competition, risk assessment and pricing in form of caveat emptor rule, contractual freedom, codes of conduct, standardization of contracts in form of master agreements), although they are not able to prevent sporadic individual defects due to fraudulent misuse of power and confidence, failure to read contractual terms or to analyze and assess investment and speculative risk, etc. Nevertheless, the objective is not to prevent all defects but rather to ensure that the markets work smoothly without major disruptions and systemic collapse. To achieve this objective, transactions in international financial markets should be mainly subject to official macroprudential oversight which might trigger adjustments to regulation of financial institutions.

\footnotetext{
${ }^{54}$ E.g. additional capital requirements (under the counter-cyclical or systemic risk buffer), recommendations as to the value of on- and off-balance sheet items, etc.

${ }_{55}$ Electricity, gas and water generation, transmission and distribution, telco, postal services, health care, etc.

${ }^{56}$ Which again means oversight and control of institutions rather than transactions.
} 


\section{References}

[1] ACKERMANN, J., June 2007. Effective regulation of international financial markets priorities for action. IIF Open Program Keynote Address.

[2] BAGEHOT, W., 1873. Lombard Street: A Description of the Money Market. London.

[3] Bank for International Settlements, May 2010. Regular OTC Derivatives Market Statistics. BIS, 11 Available at http://www.bis.org/publ/otc_hy1005.pdf

[4] Bank for International Settlement, Roles and Objectives of Central Banks, in 2009. Issues in the Governance of Central Banks. BIS, pp. 18-21.

[5] CECCHETTI, G.S. and P. DISYATAT, August 2010. Central bank tools and liquidity shortages. FRBNY Economic Policy Review, pp. 29-42.

[6] Commission of the European Communities, September 2009. Proposal for a regulation of the European Parliament and of the Council on Community macro prudential oversight of the financial system and establishing a European Systemic Risk Board. Brussels.

[7] Comptroller of the Currency, 31 March 1995. Fact Sheet. News Release, OCC NR 95-35.

[8] Council of the European Union, 2010. Council conclusions on crisis prevention, management and resolution. EU Council, Brussels. Available at http://www.consilium.europa.eu/uedocs/cms_data/docs/pressdata/en/ecofin/118266.pdf

[9] CURRY, T. and L. SHIBUT, December 2000. The Cost of the Savings and Loan Crisis: Truth and Consequences. FDIC.

[10]Federal Reserve Bank of New York, 2008. Forms of Federal Reserves Lending to Financial Institutions. FRBNY. Available at http://www.newyorkfed.org/markets/Forms_of_Fed_Lending.pdf

[11] International Swaps and Derivatives Association, 20 January 2010: Commission Communication on Cross-Border Crisis Management in the Banking Sector. Letter to Directorate-General Internal Market and Services - European Commission, ISDA.

[12] International Swaps and Derivatives Association, 31 December 2009: Cross-border Bank Resolution Group - Report and Recommendations. Letter to Basel Committee on Banking Supervision - Bank for International Settlements, ISDA.

[13] International Swaps and Derivatives Association, 3 March 2011: Possible EU Framework for Bank Recovery and Resolution. Letter to Directorate-General Internal Market and Services - European Commission, ISDA.

[14] JACKLIN, C., 1988. "Distinguishing Panics and Information-based Bank Runs: Welfare and Policy Implications,” Journal of Political Economy, Vol. 96, pp. 668-592.

[15]JILEK, J., 2006. Deriváty, hedžové fondy, offshorové společnosti. 1st edition, Prague: Grada Publishing, ISBN 80-247-1826-X.

[16] KANAS, A., May 2005. Pure contagion effects in international banking: The case of BCCI's failure. Journal of Applied Economics, Vol. 8, No. 1, pp. 101-123.

[17]LEVINE, R., November 2010. The governance of financial regulation: reform lessons from the recent crisis. BIS Working Papers no. 329, Bank for International Settlements.

[18]LLEWELLYN, D.T., 2000. Some lesson for bank regulation from recent crises. Dutch National Bank. 
[19]LODGE, M. and K. WEGRICH, 2010. Risk, regulation and financial crisis: Comparing national responses in financial regulation. Regulation in the Age of Crisis-Panels and Papers, ECPR Regulatory Governance Standing Group.

[20] The New Palgrave Dictionary of Economics, 2008. Volume 5 / edited by Durlauf, S.N. Blume, L.E. 2nd edition, Houndmills: Palgrave Macmillan.

[21]PRETTO-SAKMANN, A., 2005. Boundaries of personal property law: shares and subshares. 1st edition, Oxford: Hart Publishing, ISBN 978-1841134598.

[22] REVENDA, Z. et al., 2005. Peněžni ekonomie a bankovnictví. 4th edition, Prague: Management Press, ISBN 80-7261-132-1.

[23] SHENG, A., 55/1997. Lecture to the Macquiarie University MA (Finance) Programme in Hong Kong. Bank for International Settlements Review, BIS.

[24] Springwell Navigation Corp v JP Morgan Chase Bank, [2010] EWCA Civ 1221.

[25] THORNTON, H., 1802. An Enquiry into the Nature and Effects of the Paper Credit of Great Britain. London: Hatchard.

[26] TRICHET, J.-C., 19 November 2010. Macro-prudential oversight and the future European Systemic Risk Board. European Banking Congress, Frankfurt am Main.

[27] WALKER, G.A., 2009. Bank crisis resolution. Financial Regulation International, Issue 12.3, pp. 1-11.

[28] WALKER, G.A., February 2009. Credit crisis, Bretton Woods II and a new global response: pt 2, Butterworths Journal of International Banking and Financial Law, pp. 7581.

[29] WALKER, G.A., 2008. Sub-prime loans, inter-bank markets and financial support. The Company Lawyer, Vol. 29, Issue 1, pp. 22-25.

[30] WOOD, P., 2008. Law and Practice of International Finance. University Edition, London: Sweet \& Maxwell (Thomson Reuters), ISBN 978-1-84703-255-3. 